\title{
Bacterial Glycolipids
}

\section{GLYCOSYL DIGLYCERIDES IN GRAM-POSITIVE BACTERIA}

\author{
By D. E. BRUNDISH, N. SHAW AND J. BADDILEY \\ Microbiological Chemistry Research Laboratory, Department of Organic Chemistry, \\ University of Newcastle upon Tyne
}

(Received 16 December 1965)

\begin{abstract}
1. The lipids of ten Gram-positive bacteria have been isolated and the presence in each of a glycosyl diglyceride was established. 2. The glycolipid fractions were isolated and deacylated to give water-soluble glycosides which were purified by paper chromatography. Partial structures for the glycosides have been deduced from chemical and enzymic studies. 3. Nine of the glycosides were disaccharides glycosidically linked to the 1-position of glycerol: the remaining glycoside contained a trisaccharide similarly linked to glycerol.
\end{abstract}

The structure and distribution of phospholipids in bacteria have been intensively studied in recent years but, apart from the contributions by Lederer and his associates on the complex glycolipids of mycobacteria (Asselineau, 1962), relatively little information is available on the structure or distribution of glycolipids in bacteria. The discovery that the lipids of Pneumococcus types I and XIV contain a considerable quantity of 1-[O- $\alpha-\mathrm{D}$ galactopyranosyl - (1 $\rightarrow 2)-O$ - $\alpha-\mathrm{D}$-glucopyranosyl] 2,3-diglyceride (Brundish, Shaw \& Baddiley, 1965b; Kaufman, Kundig, Distler \& Roseman, 1965) suggested that glycolipids might be present in other organisms. The literature contains a few references to their presence in bacteria but no systematic investigation has been undertaken and no precise chemical structures have been determined. We have briefly reported the results of a preliminary survey which showed that glycosyl diglycerides are widely distributed in Grampositive bacteria (Brundish, Shaw \& Baddiley, 1965a). This paper discusses these and more recent results in detail.

\section{EXPERIMENTAL AND RESULTS}

Materials. Sephadex G-25 was purchased from Pharmacia, Uppsala, Sweden, DEAE-cellulose from H. Reeve Angel and Co. Ltd., silicic acid 'for chromatography' from L. Light and Co. Ltd., Colnbrook, Bucks., and 'Mallinckrodt 100 mesh' from Kodak Ltd., Kirkby, Lancs. Almond emulsin $\beta$-glucosidase was obtained from $L$. Light and Co. Ltd. This preparation also hydrolysed $\alpha$ - and $\beta$-galactosides.

Paper chromatography. Whatman no. 1 paper was used for descending chromatography in the system butan-1-olpyridine-water (6:4:3, by vol.) (Jeanes, Wise \& Dimler,
1951). $\alpha$-Glycols were detected by the periodate-Schiff reagents (Baddiley, Buchanan, Handschumacher \& Prescott, 1956) and sugars and polyols by the alkaline silver nitrate reagent (Trevelyan, Procter \& Harrison, 1950). Non-reducing glycosides were detected by the modified silver nitrate procedure described by Brundish et al. (1965b).

Bacteria. The organisms examined are listed in Table 1. Bacillus subtilis was a laboratory strain originally supplied by Professor M. R. J. Salton. The culture of Streptococcus faecalis 9 was supplied by Professor E. F. Gale, F.R.S. Staphylococcus saprophyticus I2 and Staph. lactis I3 were isolated by Dr A. L. Davison (Davison \& Baddiley, 1963). Bacteria were harvested at the stationary phase, washed once in sodium chloride solution and then freeze-dried.

Isolation of glycolipids. Freeze-dried cells $(5 \mathrm{~g}$.$) were$ stirred with three consecutive portions ( $150 \mathrm{ml}$. each) of chloroform-methanol $(2: 1, v / v)$ for $2 \mathrm{hr}$. and the cells were recovered by filtration. The extracts were combined and dried by rotary evaporation at room temperature, redissolved in chloroform-methanol-water (40:20:3, by vol.; $100 \mathrm{ml}$.) and non-lipid contaminants removed by passing the solution through a column ( $10 \mathrm{~g}$.) of Sephadex G-25, which was then washed with chloroform-methanol $(2: 1$, $\nabla / v$; 50ml.) (Wells \& Dittmer, 1963). Solvents were removed by rotary evaporation and then in vacuo over phosphoric oxide during $16 \mathrm{hr}$. The residue was dissolved in chloroform-methanol $(50: 1, \nabla / v ; 100 \mathrm{ml}$.) and applied to a column $(10 \mathrm{~cm} . \times 1.5 \mathrm{~cm}$.) of silicic acid [Light's silicic acid-Mallinckrodt silicic acid $(1: 1, w / w)]$. Neutral lipids were eluted with chloroform-methanol (50:1, v/v; $100 \mathrm{ml}$.) and the polar lipids were recovered by elution with chloroform-methanol $(1: 1, \nabla / v ; 60 \mathrm{ml}$.) followed by methanol $(60 \mathrm{ml}$.). The polar lipid fraction was dried by rotary evaporation and redissolved in chloroform-methanol $(19: 1, \mathrm{v} / \mathrm{v} ; 50 \mathrm{ml}$.). The solution was applied to a column $(20 \mathrm{~cm} . \times 2 \mathrm{~cm}$.) of DEAE-cellulose (acetate form) and eluted with chloroform-methanol $(17: 3, \mathrm{v} / \mathrm{v} ; 50 \mathrm{ml}$.) to give the 'glycolipid fraction'. A phospholipid fraction was recovered by elution with chloroform-methanol (2:1, $\mathbf{v} / \mathbf{v}$; $150 \mathrm{ml}$.) containing $0.4 \%$ of ammonium acetate. Samples 
Table 1. Glycosides obtained by deacylation of glycolipids from various Gram-positive bacteria

\begin{tabular}{|c|c|c|c|c|c|}
\hline Organism & $\begin{array}{l}\text { Products } \\
\text { of acid } \\
\text { hydrolysis }\end{array}$ & $\begin{array}{l}\text { Products of } \\
\text { partial acid } \\
\text { hydrolysis }\end{array}$ & $\begin{array}{l}\text { Products of } \\
\text { enzymic } \\
\text { hydrolysis }\end{array}$ & $\begin{array}{c}R_{\mathrm{Glc}} \text { in } \\
\text { butan-1-ol- } \\
\text { pyridine- } \\
\text { water }\end{array}$ & Partial structure \\
\hline $\begin{array}{l}\text { Pneumococcus, rough } \\
\text { type I* }\end{array}$ & $\begin{array}{l}\text { Glucose, } \\
\text { galactose, } \\
\text { glycerol }\end{array}$ & $\begin{array}{l}\text { Galactose, } \\
\text { glucosylglycerol }\end{array}$ & $\begin{array}{l}\text { Galactose, } \\
\text { glucosylglycerol }\end{array}$ & 0.43 & - \\
\hline $\begin{array}{l}\text { Lactobacillus casei } \\
\text { A.T.C.C. } 7469 \\
\text { Lactobacillus buchneri } \\
\text { N.C.I.B. } 8007\end{array}$ & $\left\{\begin{array}{l}\text { Glucose, } \\
\text { galactose, } \\
\text { glycerol }\end{array}\right.$ & $\begin{array}{l}\text { Galactose, } \\
\text { glucosylglycerol }\end{array}$ & $\begin{array}{l}\text { Galactose, } \\
\text { glucosylglycerol }\end{array}$ & 0.43 & $\begin{array}{l}\text { Galactosyl- } \alpha \text {-glucosyl- } \\
(1 \rightarrow 1) \text {-glycerol }\end{array}$ \\
\hline $\begin{array}{l}\text { Bacillus subtilis } \\
\text { Staphylococcus } \\
\text { saprophyticus I2 }\end{array}$ & & & & & \\
\hline $\begin{array}{l}\text { saprophyticus I2 } \\
\text { Staphylococus lactis I3 } \\
\text { Staphylococous lactis } \\
\text { N.C.T.C. } 7944\end{array}$ & $\begin{array}{l}\text { Glucose, } \\
\text { glycerol }\end{array}$ & $\begin{array}{l}\text { Glucose, } \\
\text { glucosylglycerol }\end{array}$ & $\begin{array}{l}\text { Glucose, } \\
\text { glycerol }\end{array}$ & 0.49 & $\begin{array}{l}\beta \text {-Glucosyl- } \beta \text {-glucosyl- } \\
(1 \rightarrow 1) \text {-glycerol }\end{array}$ \\
\hline $\begin{array}{l}\text { Staphylococcus aureus } \mathrm{H} \\
\text { Streptococcus faecalis } 9\end{array}$ & $\begin{array}{l}\text { Glucose, } \\
\text { glycerol }\end{array}$ & $\begin{array}{l}\text { Glucose, } \\
\text { glucosylglycerol }\end{array}$ & Stable & 0.53 & $\begin{array}{c}\alpha \text {-Glucosylglucosyl- } \\
(1 \rightarrow 1) \text {-glycerol }\end{array}$ \\
\hline $\begin{array}{l}\text { Micrococcus lysodeikticus } \\
\text { A.T.C.C. } 4698\end{array}$ & $\begin{array}{l}\text { Mannose, } \\
\text { glycerol }\end{array}$ & $\begin{array}{l}\text { Mannose, } \\
\text { mannosylglycerol }\end{array}$ & - & 0.51 & $\begin{array}{l}\text { Mannosylmannosyl- } \\
(1 \rightarrow 1) \text {-glycerol }\end{array}$ \\
\hline $\begin{array}{l}\text { Lactobacillus plantarum } \\
\text { 17-5 }\end{array}$ & $\begin{array}{l}\text { Glucose, } \\
\text { galactose, } \\
\text { glycerol }\end{array}$ & $\begin{array}{l}\text { Glucosylgalactose, } \\
\text { glucosylglycerol }\end{array}$ & $\begin{array}{l}\text { Galactose, } \\
\text { glucose, } \\
\text { glycerol }\end{array}$ & 0.22 & $\begin{array}{l}\beta \text {-Glucosylgalactosyl- } \\
\beta \text {-glucosyl-(1 } \rightarrow 1) \text { - } \\
\text { glycerol }\end{array}$ \\
\hline
\end{tabular}

* Included for purposes of comparison. For full structure determination see Brundish et al. (1965b).

(1 mg.) of the neutral lipid, glycolipid and phospholipid fractions were deacylated (Marinetti, 1962) and examined by paper chromatography: only the glycolipid fraction yielded a glycoside after this treatment.

Isolation of glycosides. The glycolipid fraction was dissolved in chloroform-methanol $(1: 1, \nabla / v ; 4 \mathrm{ml}$.$) and$ deacylated by the method of Marinetti (1962). After deacylation had proceeded for $10 \mathrm{~min}$. water $(5 \mathrm{ml}$.) was added to the mixture and the separated aqueous phase was deionized by passage through a column (3ml.) of Dowex $50 \mathrm{H}^{+}$form $)$resin. The eluate was evaporated to a small volume and applied as a band to the origin of a paper chromatogram. After development the glycosides were eluted from the appropriate areas of the paper with water. The average yield of glycoside obtained indicated that the glycolipid represented approximately 1-2\% of the total lipid of the organism. The glycosides were dissolved in water $\left(2.5 \mathrm{mg} . / \mathrm{ml}\right.$.) and the solutions were kept at $4^{\circ}$.

\section{Examination of glycosides}

Paper chromatography. The $R_{\mathrm{Glc}}$ values are given in Table 1. The glycosides were conveniently detected by the modified silver nitrate procedure and rapidly gave a purple colour with the periodate-Schiff reagents indicative of formaldehyde produced from a 1-substituted glycerol (Roberts, Buchanan \& Baddiley, 1963); the purple colour slowly changed to blue.

Acid hydrolysis. Samples $(0.2 \mathrm{ml}$.) of the solutions of glycosides were heated with an equal volume of $4 \mathrm{~N}$-hydrochloric acid at $100^{\circ}$ for $1 \mathrm{hr}$. The hydrolysates were dried in vacuo (over potassium hydroxide) and examined by paper chromatography for the presence of sugars and polyols. The results are given in Table 1.

Partial acid hydrolysis. Samples $(0.3 \mathrm{ml}$.) of the solutions of glycosides were heated with $0.2 \mathrm{~N}$-hydrochloric acid $\left(0.3 \mathrm{ml}\right.$.) for $40 \mathrm{~min}$. at $100^{\circ}$. The hydrolysates were evaporated to dryness in vacuo (over potassium hydroxide) and examined by paper chromatography for the presence of sugars, polyols and glycosides. The glycosides from B. subtilis, Staph. aureus, Staph. lactis (two strains), Staph. saprophyticus and Strep. faecalis all yielded glucose and glucosylglycerol. Although the latter has $R_{\mathrm{Gle}} 1.0 \mathrm{its}$ presence was readily established by the rapid appearance of a purple colour when treated with the periodate-Schiff reagents. The glycosides from Lactobacillus casei and $L$. buchneri both yielded galactose and a glucosylglycerol. Samples of the latter compound from both organisms were obtained by elution from the paper with water; they were hydrolysed in acid to give in each case only glucose and glycerol. The glycoside from Micrococcus lysodeikticus gave mannose and a glycosylglycerol which was hydrolysed further to mannose and glycerol. The glycoside from $L$. plantarum yielded, in addition to glucosylglycerol, a reducing disaccharide, $R_{\mathrm{Glo}} \mathbf{0 \cdot 4 3}$, and traces of glucose and galactose. The disaccharide was eluted from the paper with water and the solution $(0.2 \mathrm{ml}$.) was divided into two equal portions. The first was neated with $4 \mathrm{~N}$-hydrochloric acid $\left(0.1 \mathrm{ml}\right.$.) at $100^{\circ}$ for $1 \mathrm{hr}$., when the products were glucose and galactose. The second portion was treated with sodium borohydride (5mg.) for $16 \mathrm{hr}$. at $2^{\circ}$. Excess of borohydride was destroyed by the addition of a drop of acetic acid and the solution was passed through a column (1 ml.) of Dowex $50\left(\mathrm{H}^{+}\right.$form $)$resin. The eluate was evaporated to dryness 
and boric acid was removed by evaporation with three successive portions ( $1 \mathrm{ml}$. each) of methanol on a steam bath. The residue was dissolved in $2 \mathrm{~N}$-hydrochloric acid $\left(0.2 \mathrm{ml}\right.$.) and heated at $100^{\circ}$ for $1 \mathrm{hr}$. The products were glucose and galactitol which establish the structure of the original disaccharide as glucosylgalactose.

Enzymic hydrolysis. Samples $(0 \cdot 1 \mathrm{ml}$.) of the solutions of glycosides were incubated at $37^{\circ}$ for $24 \mathrm{hr}$. with an equal volume of almond emulsin $\beta$-glucosidase solution $(2 \%$, $w / v)$, dried and examined by paper chromatography. The results are given in Table 1 .

\section{DISCUSSION}

The first isolation of a glycosyl diglyceride from bacterial lipids was described by Macfarlane (1961), who proposed the structure mannosyl diglyceride for the glycolipid from $M$. lysodeikticus N.C.T.C. 2665. Lennarz (1964) found a dimannosyl diglyceride in another strain (A.T.C.C. 4698) of the same organism. Macfarlane (1962a) found a lipid containing mannose in Clostridium welchii and a glucosyl diglyceride in Staph. aureus (Macfarlane, 1962b). In a study of the lipids of Staph. aureus Polonovski, Wald \& Paysant-Diament (1962) found that the major glycolipid was diglucosyl diglyceride, although traces of a monoglucosyl compound were also detected. The presence of traces of glucose and galactose in the hydrolysates of lipids from several lactobacilli led Ikawa (1963) to postulate the occurrence of glycolipids in these organisms. These reports together with our investigations on the glycolipids of Pneumococcus (Brundish et al. 1965b) prompted the present survey.

Ten strains of Gram-positive bacteria were examined for the occurrence of glycolipids and the presence in each of a glycosyl diglyceride establishes that these compounds are widely distributed. A fraction containing the glycolipid was separated from other lipids by chromatography on columns of silicic acid and DEAE-cellulose. After deacylation the glycosides derived from the glycolipids were isolated by paper chromatography and partial structures were established by chemical and enzymic hydrolysis (Table 1). The chromatographic behaviour of all the glycosides except that from $L$. plantarum indicated that they were diglycosylglycerol isomers. They rapidly gave a purple colour with the periodate-Schiff reagents indicative of formaldehyde produced from a 1-substituted glycerol (Roberts et al. 1963). The glycosides from B. subtilis, Staph. aureus, Staph. saprophyticus and two strains of Staph. lactis all had the same mobility on paper chromatography and gave glucose and glycerol on hydrolysis in acid. Partial hydrolysis with acid gave glucose and glucosylglycerol, whereas enzymic hydrolysis with almond emulsin completely degraded the glyco- sides to glucose and glycerol. These results indicate the partial structure $\beta$-glucosyl- $\beta$-glucosyl- $(1 \rightarrow 1)$ glycerol. Acid hydrolysis also showed that the glycoside from Strep. faecalis was a diglucosylglycerol but it moved consistently faster on paper chromatography than did the other five. This apparent structural difference was supported by the resistance of the glycoside to hydrolysis by almond emulsin, and it is likely that the glycoside is an $\alpha$-glucosyl-glucosyl-( $1 \rightarrow 1)$-glycerol. The glycosides from $L$. case $i$ and $L$. buchneri both gave on partial acid hydrolysis galactose and a glucosylglycerol, thereby establishing the sequence as galactosylglucosylglycerol. Enzymic hydrolysis yielded galactose and glucosylglycerol, but as the enzyme preparation contained both $\alpha$ - and $\beta$ galactosidases this experiment only establishes the $\alpha$-configuration of the glucose-glycerol linkage. The glycoside from $M$. lysodeikticus was a dimannosylglycerol, a finding which agrees with the work of Lennarz (1964). It seems probable that the glycolipid from this organism reported by Macfarlane (1961) as a monomannosyl diglyceride is in fact the dimannosyl diglyceride.

The glycoside from $L$. plantarum had a much lower mobility on paper chromatograms than did the diglycosylglycerols from the other organisms although it gave the characteristic periodateSchiff reaction for a 1 -substituted glycerol. Hydrolysis in acid showed that it contained glucose, galactose and glycerol, and partial acid hydrolysis yielded a glucosylglycerol and a glucosylgalactose: almond emulsin completely hydrolysed it to glucose, galactose and glycerol. The results suggest the partial structure $\beta$-glucosyl-galactosyl- $\beta$-glucosyl-(1 $\rightarrow 1)$-glycerol. The lipids of the Pneumococcus contain, in addition to a diglycosyl diglyceride, a monoglucosyl diglyceride which in the rough type I represents about $1 \%$ of the total glycolipid. Similar compounds were not detected in the present survey, although if they were present in comparable amounts they might well have escaped detection. However, in $L$. casei and Strep. faecalis traces of glycosides were detected which, from their chromatographic properties, are probably much larger than others reported here. Lennarz (1964) was able to demonstrate the formation of small amounts of a trimannosyl diglyceride in cell-free extracts of $M$. lysodeikticus although he could not isolate this compound from whole cells.

While this work was in progress Vorbeck \& Marinetti $(1964,1965)$ have reported briefly the presence of a glucosyl diglyceride and a galactosylglucosyl diglyceride in Strep. faecalis A.T.C.C. 9790, and also an uncharacterized glycolipid in $L$. plantarum B-246. Polonovski, Wald \& Petek (1965) have studied more fully the glycoside from Staph. aureus and have suggested from methylation 
studies that it is a mixture of two compounds: glucosyl - $(1 \rightarrow 6)$ - glucosyl - $(1 \rightarrow 1)$ - glycerol and glucosyl-( $1 \rightarrow 3)$-glucosyl-( $1 \rightarrow 1)$-glycerol. It is possible that some of the glycosides described here may be mixtures of isomers, since paper chromatography may fail to separate closely related isomers. The glycoside from the Pneumococcus, however, which has been obtained crystalline, is a homogeneous compound and its structure has been confirmed by chemical synthesis (Brundish, Shaw \& Baddiley, 1966). The survey has not yet been extended to Gram-negative organisms but the isolation by Reeves, Latour \& Lousteau (1964) of 1-O- $\beta$-D-galactofuranosylglycerol from the lipids of Bacteroides symbiosus, incorrectly claimed to be the first example of a natural galactofuranoside, suggests that similar compounds may occur in Gram-negative bacteria.

Glycosyl diglycerides were first reported by Carter, McCluer \& Slifer (1956) as components of the lipids of wheat flour; their structures were shown to be 1-[O- $\alpha$-D-galactopyranosyl-(1-6)-O- $\beta$-D-galactopyranosyl] 2,3-diglyceride and 1-O- $\beta$-D-galactopyranosyl 2,3-diglyceride. These galactolipids appear to be universally distributed in the plant kingdom and the structure of the hydrophilic groups is in all cases the same. Benson, Wintermans \& Wiser (1959) suggested that these compounds might be concerned in the transport of galactosyl groups between the adsorbed lipids and the pool of intermediates in carbohydrate synthesis in Chlorella. Macfarlane (1961) extended this hypothesis to the mannosyl diglyceride of $M$. lysodeikticus, which she suggested as a transport device for mannose in the biosynthesis of the mannan present in the membrane of this organism. Distler \& Roseman (1964) suggested that the galactosylglucosyl diglyceride in the Pneumococcus type XIV might be involved in the biosynthesis of the capsular polysaccharide which contains glucose and galactose. It may be significant that in the Pneumococcus the glycolipid represents over $30 \%$ of the total lipid whereas in the other organisms it accounts for only $1-2 \%$ of the lipid material. In this respect a study of other capsulated organisms would be of interest. Recent work by Rothfield \& Horecker (1964) has shown that phosphatidylethanolamine is essential for the biosynthesis of the lipopolysaccharide of Salmonella typhimurium and Anderson, Matsuhashi, Haskin \& Strominger (1965) have demonstrated the presence of a lipid intermediate in cell-wall biosynthesis in Staph. aureus. Although there is no direct evidence yet concerning a metabolic function for the glycolipids described here, an involvement in sugar transport provides an attractive hypothesis. Moreover, a possible role in polysaccharide synthesis is suggested by the presence of traces of larger compounds in
Strep. faecalis and $L$. casei. These compounds may occur in the cell in larger amounts than was suggested by our present observations since the increased size of their hydrophilic groups would probably result in greatly decreased solubility in lipid solvents and consequent failure to be extracted efficiently. It is also possible that they may only accumulate in the lipids during the early stages of growth of the cell.

D. E. B. held the George Angus Studentship during this work, which was supported by grants from the U.S. Public Health Service (AI-05237-02-BIO) and the Science Research Council.

\section{REFERENCES}

Anderson, J. S., Matsuhashi, M., Haskin, M. \& Strominger, J. L. (1965). Proc. nat. Acad. Sci., Wash., 53, 881.

Asselineau, J. (1962). Les Lipides Bactériens. Paris: Hermann et Cie.

Baddiley, J., Buchanan, J. G., Handschumacher, R. E. \& Prescott, J. F. (1956). J. chem. Soc. p. 2818.

Benson, A. A., Wintermans, J. F. G. M. \& Wiser, R. (1959). Plant Physiol. 34, 315.

Brundish, D. E., Shaw, N. \& Baddiley, J. (1965a). Biochem. $J .95,21$ c.

Brundish, D. E., Shaw, N. \& Baddiley, J. (1965b). Biochem. J. 97, 158.

Brundish, D. E., Shaw, N. \& Baddiley, J. (1966). J. chem. Soc. C, p. 521.

Carter, H. E., McCluer, R. H. \& Slifer, E. D. (1956). J. Amer. chem. Soc. 78, 3735.

Davison, A. L. \& Baddiley, J. (1963). J. gen. Microbiol. $32,271$.

Distler, J. \& Roseman, S. (1964). Proc. nat. Acad. Sci., Wash., 51, 897.

Ikawa, M. (1963). J. Bact. 85, 772.

Jeanes, A., Wise, C. S. \& Dimler, R. J. (1951). Analyt. Chem. 23, 415.

Kaufman, B., Kundig, F. D., Distler, J. \& Roseman, S. (1965). Biochem. biophys. Res. Commun. 18, 312.

Lennarz, W. J. (1964). J. biol. Chem. 239, po3110.

Macfarlane, M. G. (1961). Biochem.J. 80, 45 P.

Macfarlane, M. G. (1962a). Nature, Lond., 196, 136.

Macfarlane, M. G. (1962b). Biochem. J. 82, 40 P.

Marinetti, G. V. (1962). J. Lipid Res. 3, 1.

Polonovski, J., Wald, R. \& Paysant-Diament, M. (1962). Ann. Inst. Pasteur, 103, 32.

Polonorski, J., Wald, R. \& Petek, F. (1965). Bull. Soc. Chim. biol., Paris, 47, 409.

Reeves, R. E., Latour, N. E. \& Lousteau, R. J. (1964). Biochemistry, 3, 1248.

Roberts, W. K., Buchanan, J. G. \& Baddiley, J. (1963). Biochem. J. 88, 1.

Rothfield, L. \& Horecker, B. L. (1964). Proc. nat. Acad. Sci., Wash., 52, 939.

Trevelyan, W. E., Procter, D. P. \& Harrison, J. S. (1950). Nature, Lond., 166, 444.

Vorbeck, M. L. \& Marinetti, G. V. (1964). Fed. Proc. 23, 375.

Vorbeck, M. L. \& Marinetti, G. V. (1965). J. Lipid Res. 6, 3. Wells, M. A. \& Dittmer, J. C. (1963). Biochemistry, 2, 1259. 